\title{
RISIKO PRODUKSI DAN INEFISIENSI TEKNIS \\ USAHATANI PADI GOGO PADA AGROEKOSISTEM LAHAN KERING
}

\author{
PRODUCTION RISK AND TECHNICAL INEFFICIENCY \\ FOR GOGO RICE FARMING ON DRY LAND AGROECOSYSTEM
}

\author{
Disusun Oleh : \\ Kustiawati Ningsih \\ Program Studi Agribisnis, Fakultas Pertanian, Universitas Islam Madura Pamekasan
}

\begin{abstract}
ABSTRAK
Usaha dibidang pertanian berada dalam situasi ketidakpastian, akibatnya tidak pernah memiliki hasil pasti. Sumber ketidakpastian yang penting di sektor pertanian adalah fluktuasi hasil pertanian dan fluktuasi harga. Ketidakpastian prediksi hasil pertanian lebih banyak disebabkan oleh faktor alam. Sebagai contoh faktor alam yang bersifat tidak menentu dan sulit dikontrol petani adalah iklim yang kurang menguntungkan, serangan hama dan penyakit, kekeringan dan banjir. Kesemuanya itu merupakan faktor yang dapat menurunkan produksi, bahkan seringkali petani tidak memperoleh sesuatu apapun dari hasil usahanya. Ketidakpastian tentang prediksi harga disebabkan begitu kompleksnya faktor yang menyebabkan fluktuasi harga. Adanya spekulasi pedagang yang cenderung ingin memperoleh keuntungan besar dan rantai pemasaran yang panjang merupakan faktor berpengaruh terhadap naik turunnya harga yang sering merugikan petani. Tujuan penelitian ini adalah untuk menganalisis risiko produksi pada usahatani padi gogo pada agroekosistem lahan kering dan menganalisis efisiensi teknis pada usahatani padi gogo. Lokasi penelitian ditentukan secara purposive yaitu di Desa Sentol, Kecamatan Pademawu. Pengambilan sampel menggunakan metode yang mengacu pada pendapat Cochran (2005) yaitu proportional sampling. Hasil penelitian yang diperoleh adalah pada agroekosistem lahan kering, risiko produksi padi gogo yang terjadi cukup tinggi. Kesimpulan ini diputuskan dengan mengacu pada hasil nilai Coefficient Variation (CVx) usahatani padi gogo di lahan kering sebesar 0,48. Hasil analisis efisiensi teknis menyimpulkan bahwa kegiatan usahatani padi gogo di Desa Sentol, Kecamatan Pademawu ternyata petani atau produsen berperilaku tidak efisien secara teknis.
\end{abstract}

Kata Kunci : Risiko Produksi, Inefisiensi Teknis

\begin{abstract}
The efforts in agricultural field were in uncertainty situation, with the result that there were never certain results. Important uncertainty sources in the agricultural field were agricultural yield and price fluctuation. Uncertainty of agricultural yield prediction was much caused by natural factors. Some of uncertain and uncontrollable natural factors by farmers were unbeneficially climate, pests and plant diseases raids, droughts and floods. All of these were factors which could decrease production, even farmers often times gained nothing from their efforts. Uncertainty about price prediction was caused by factors that were so complex which brought price fulctuation. Two influential factors to up and down price which often brought disadvantages to farmers were dealer speculation which tended to gain high profit and long market chain. The objectives of this research were to analyze the production risks of gogo rice farming in dry land and to analyze the technical efficiency of gogo rice farming.The research location was determined purposively that was in Sentol Village, Pademawu District. The sampling method which refers to the opinion of Cochran (2005) that was proportional sampling. The research results was in dryland agroecosystem, production risk of gogo rice occurring is high. This conclusion is decided by reference to the Coefficient of Variation $(\mathrm{CVx})$ gogo rice farming in dry land 0.48 . The analysis results of technical efficiency concluded that rice farmers or producers behaved inefficient technically in Sentol Village, Pademawu District farming activities.
\end{abstract}

Key word : Production Risk, Technical Inefficiency 